\title{
Sovereign Wealth Fund Investments and Firm Value
}

\author{
Dinh Bao Ngoc ${ }^{1}$ \\ ${ }^{1}$ Department of Finance, University of Economics, The University of Danang, Vietnam \\ Correspondence: Dinh Bao Ngoc, University of Economics, 71 Ngu Hanh Son St., Danang city, Vietnam. Tel: \\ 84-914-303-060. E-mail: ngocdb@due.edu.vn
}

Received: July 27, 2015

Accepted: September 6, 2015

Online Published: September 25, 2015

doi:10.5539/ijef.v7n10p100

URL: http://dx.doi.org/10.5539/ijef.v7n10p100

\begin{abstract}
This research aims to analyze the impact of Sovereign Wealth Fund (SWF) investments on the values of companies in which they invest. We attempt to provide evidences of the effects of SWF investment activities by examining the short-term impact of SWF investments on the performance of the companies. In order to quantify the valuation effects of SWF investments, we collect data on equity investments for each SWF and we use the event study methodology to estimate abnormal returns to the shares around the times that news of the transactions of SWFs becomes publicly available. The sample consists of 61 investments by 11 important SWFs from around the world (China, Singapore, United Arab Emirates, Russia, France etc.) during the period 2003 to 2014. We find that the anouncement effect of SWF investments in the listed companies is positive and the level of transparency of SWFs influence the positive impact of SWF investments on the performance of those companies in which they invest.
\end{abstract}

Keywords: sovereign wealth fund, investment, transparency, firm value, event study

\section{Introduction}

The Sovereign Wealth Funds (SWFs) are special investment funds created or owned by a government to hold foreign assets for long term purposes. SWFs have recently gained media attention because of concerns about their large size, rapid growth and lack of transparency. The popular press and the general public have both become extremely active in discussing the potential impact of SWFs. However, there has been very little academic research in this domain so far.

SWFs play an important role in macroeconomic management and global financial stability. During the global financial crisis in 2008, the role of SWFs as liquidity providers for the global financial markets in the credit crisis is very important. Some empirical studies find the positive impact of SWF investments on the values of the companies in which they invest (Chhaochharia \& Laeven, 2008; Fotak, Bortolotti, \& Megginson, 2008); Kotter \& Lel, 2008; Dewenter, Han, \& Malatesta, 2009). However, economists worry about the investment of SWFs. It is likely that the market reacts negatively to the announcements of SWF investments. The agency cost theory predicts that large investors might force the company to act in their own interest, against the interests of other investors, employees or managers. Since SWF is as a large investor this argument supposes that SWFs are likely to impose goals and priorities which are inconsistent with profit maximization of the firms. Therefore, this creates high agency costs and a fall of the firm value.

Taking account of these contradictions, we analyze the impact of SWF investments on the performance of the firms. However, due to difficulties in collecting the data, we consider only the immediate impact of SWF investments on the performance of the firms. Based on the investigation of the returns to target firm shareholders subsequent to these investments, we are able to determine whether the effects of SWF investments in the companies on balance create or reduce value. Our results are consistent with those of the previous studies and this allows us to confirm the positive impact of SWF investments on the performance of the companies.

In this paper, firstly, a literature review summarizes the previous studies about the market reaction to announcements of investments by SWFs. Next, we present and explain the methodology and the data of our research. Finally, the empirical results and conclusions regarding the impact of SWF investments on the performance of the companies are clearly revealed. 


\section{Literature Review}

SWFs are defined as special purpose investment funds or arrangements, owned by the general government. Created by the general government for macroeconomic purposes, SWFs hold, manage, or administer assets to achieve financial objectives. They also employ a set of investment strategies which also include investment in foreign financial assets. SWFs are commonly established out of balance of payments surpluses, official foreign currency operations, the proceeds of privatizations, fiscal surpluses, and/or receipts resulting from commodity exports (International working group of SWFs-IWG).

SWFs have been existing for decades (the Kuwait Investment Authority were established as early as 1953). However, they have only attracted considerable public attention in recent years. SWFs offer a variety of economic and financial benefits. Indeed, a number of SWFs participated in stabilization of their own domestic markets and international markets during the crisis in 2008 and early 2009. SWFs invested in equities experienced large losses from the sharp decline in equity markets. However, they recovered most of the losses in the subsequent years by demonstrating their willingness to be long-term investors and riding out the financial turmoil (IMF 2011, and Papaioannou \& others, 2013).

SWFs play an important role in companies in which they invest. If large investors possess superior information their transactions will influence firm values through signaling. In addition, existing theories indicate that there are two other effects of large shareholders on firm value and these effects vary with the level of ownership. Shleifer and Vishny (1986) indicated that large shareholders have incentives to monitor firm activities and can provide a partial solution to the free-rider problem which was also discussed by Grossman and Hart (1980). It has been shown that large shareholders can improve firm values by facilitating beneficial takeovers. Otherwise they lead firms to adopt value-added improvements. In addition, SWFs can be used by governments in order to pursue a variety of nonfinancial social objectives. Companies in which SWFs take large stakes may be influenced to choose employment levels, production technologies, and product mixes that are calculated to achieve social policy objectives rather than purely financial returns. Even if SWFs are entirely passive investors their investment selections may reflect broader and more complex, nonfinancial, and objectives than those of private investors. As a result, large SWF investments may convey valuation signals which differ from those of large private investments and monitoring by SWFs may not produce financial benefits that, in theory, flow from the monitoring activities of large private investors.

On the other hand, the agency cost theory which was developed by Jensen and Meckling (1976) predicts that large shareholders impose agency costs on firms. Their motives might not be always consistent with risk-adjusted profit maximization and SWFs might force the company to act in their own interest. In addition, due to their lack of transparency and the uncertainty associated with their behavior as shareholders, SWFs could impose agency costs and therefore additional agency costs would result in a decrease in the firm value.

So far, there have been several empirical studies focusing on the impact of SWF investments on firm values. Chhaochharia and Laeven (2008) showed that the announcement effect of SWFs investments in listed equities is positive. Based on their study, share prices of firms exhibit a favourable response when SWFs buy stakes, because these investments occur when firms are in financial distress. However, the long-run performance of equity investments by SWFs tends to be poor, coherent with imperfect portfolio diversification and poor corporate governance. The research of Fotak, Bortolotti and Megginson (2008) about the sovereign wealth fund investments which was built based on the previous literatures seeks to determine whether sovereign wealth investments create value for the companies in which they invest by analyzing the market adjusted short and long term returns on the sovereign wealth investments in equity in the United States. The results obtained by this empirical research are similar to those of the previous studies about the announcement effect of SWF investments. In fact, stocks of targeted firm exhibit positive abnormal returns when SWF investments are announced and this is considered as evidence from investors to welcome SWFs. In addition, the greater the share of the firm acquired by the SWF and the greater the level of transparency of the funds itself, the stronger the positive reaction. More importantly, SWFs are associated with deteriorating firm performance over two years subsequent to the initial SWF investment. They concluded that SWFs have a negative impact on firm profitability in the long term, perhaps by imposing additional agency costs.

Kotter and Lel (2008) described that the market reacts positively to announcements of investments by SWFs, which is originated from SWF investments in firms facing financial difficulties and the information generation of stock selection by the funds. Moreover, according to this study, the degree of SWF transparency is related to the market reaction. However, SWF investments do not remarkably impact target firms profitability, growth and governance in the three-year following the investment. Dewenter, Han and Malatesta (2009) indicated positive 
market reactions to acquisitions announcement and negative to divestment announcement of SWFs. They also claimed that in a long-term analysis, the hypothesis which stocks bought and sold by SWFs earn normal returns afterwards is not rejected. Neverthelese, the results in the long-run obtained by Nuno Fernandes (2009) and Sojli and Tham (2010) are different with the previous results. In particular, Nuno Fernandes (2009) proved that firms possessing higher SWF ownership have higher firm valuations and better operating performance and SWFs have contribution to create long-term shareholder value. Sojli and Tham (2010) also found that in the short-term, the markets welcome SWF investments and in the long-term the level of internationalization and Tobin's q of the firms increase substantially after SWF investments.

Using the random effect models and appraisal ratios of monthly returns as dependent variables, Knill, Lee and Mauck (2012a) examined the relationship between SWF investments and the return-to-risk performance of firms. In particular, SWF investment creates the deterioration in return-to-risk performance in the long run (one-, threeand five-year windows). In addition, these authors claimed that the decreased return experienced by firms is not sufficiently compensated by the corresponding decrease in risk by these firms. This research also criticized the previous studies (Kotter \& Lel, 2011; and Dewenter, Han, \& Malatesta, 2009) since their abnormal return calculations do not take into account investment risks.

Recently, In, Park, and Lee (2013) investigated the SWF investments and the stabilization of the stock markets. Based on the measurement of the tail risk of SWF investments and taking into account the heterogeneity of SWF groups, they showed that SWF investments generally have a destabilizing effect on the stock markets. On the other hand, a stabilizing effect, particularly in crisis periods from August 2007 to December 2009, has been observed because of SWFs with savings objectives. The important role of the foreign investments of SWFs in the stabilization of international stock markets during the financial crisis period has been also mentioned in this study. In addition, these authors proposed significant liquity which is provided by SWFs.

Although several studies mentioned above examine the impact of SWF investments on the values of the companies, they do not analyse clearly the influence of the level of transparency of SWFs on the market reaction to the announcements of SWF investments. In this paper, the principal hypothesis we would like to investigate is that the market reacts favorably to the announcements of SWF investments and the level of transparency of SWFs influence the positive reaction of the announcements of the SWFs acquisition on the share prices of the companies.

\section{Data and Methodology}

Objective of this research is to analyze the impact of SWF investments and the influence of transparency of SWFs on the value of companies. In order to obtain this goal, the reaction of market to the announcements of SWF investments is carefully investigated. It is useful to recall that because of the difficulty in collecting the data, only the immediate impact of SWF investments on the firm value is considered.

Taking account different arguments and empirical research presented in the literature review, the principle hypothesis which is proposed to test in this study is that the market reacts positively to the announcements of SWF investments.

Firstly, in order to quantify the valuation effects of SWF investments, we use the event study methodology to estimate abnormal returns of the shares around the time that news of the transactions of SWFs becomes publicly available. This allows us to be able to determine whether the SWF investments create or reduce value. The announcement period abnormal returns are estimated over the event windows for each transaction. We searched both the Factiva and the Lexis Nexis new source databases to achieve the announcement dates for these transactions.

The sample used in this study consists of 61 investments in listed companies by 11 important SWFs of 6 countries around the world during the period 2003 to 2014.

Table 1. Sovereign wealth funds and the number of observations

\begin{tabular}{lc}
\hline Sovereign Wealth Funds & Number of observations \\
Government of Singapore Investment Corporation (GIC) & 14 \\
Temasek Holdings - Singapore & 11 \\
China Investment Corporation (CIC) & 9 \\
Strategic Investment Fund - France & 9 \\
Abu Dhabi Investment Authority (ADIA) & 5 \\
\hline
\end{tabular}




\begin{tabular}{lc}
\hline SAFE Investment Company - China & 4 \\
Kuwait Investment Authority (KIA) & 3 \\
Qatar Investment Authority (QIA) & 2 \\
Investment Corporation of Dubai (ICD) & 2 \\
Dubai World Holdings Ltd -UAE & \multicolumn{2}{|c}{1} \\
Mubadala Development Company - UAE Abu Dhabi & \multicolumn{2}{|c}{} \\
Total & $\mathbf{6 1}$ \\
\hline
\end{tabular}

After choosing a sample for our study, we collect the necessary data to perform an event study methodology. Using the Datastream database, we obtain the daily stock price of target firms to calculate the return of the company. For the return of the market, the price index (PI) of market calculated by Datastream is used.

The following steps are taken for implementing the event study:

\section{- Identification of the event window}

We examine different event windows $[t-10, t+5],[t-3, t+3],[t-1, t+1],[t+2, t+10] \ldots$ over the period $[t-$ $40, t+20]$. Let $\mathrm{t}=0$ represent the time of the event.

- Determination of a expected return of the security i for time $t$ during the event window in the absence of the event $\left(K_{i t}\right)$

We use a simple market model to estimate coefficient $\alpha$ and $\beta$ of firms:

$$
R_{i t}=\alpha_{i}+\beta_{i} R_{M t}+\varepsilon_{i t} \quad t € I_{N}
$$

For each event, the market model is estimated over the period 400 to 50 trading days prior to the event date.

Then, the expected return $\mathrm{K}_{\mathrm{it}}$ is estimated for time $\mathrm{t}$ during the event window:

$$
K_{i t}=\alpha_{i}+\beta_{i} R_{M t} \quad t \in I
$$

- Calculation of the abnormal return within the event window

We calculate the abnormal returns by differencing the observed return $\mathrm{R}_{\mathrm{it}}$ and the expected return $\mathrm{K}_{\mathrm{it}}$ : AR

$$
A R_{i t}=R_{i t}-K_{i t}
$$

- Calculation of the average abnormal return $(A A R)$ and the cumulative average abnormal return (CAAR)

Given $\mathrm{N}$ events (a total of 61 in the entire sample), the sample average aggregated abnormal return for period $\mathrm{t}$ is:

$$
\operatorname{AAR}_{\mathrm{t}}=\frac{1}{\mathrm{~N}} \sum_{\mathrm{i}=1}^{\mathrm{N}} \mathrm{AR}_{\mathrm{it}}
$$

The average abnormal return can then be aggregated over the event window to calculate the cumulative average abnormal return for each firm i:

$$
C A A R_{t 1, t 2}=\sum_{t=t 1}^{t 2} A A R_{t}
$$

Testing whether the abnormal return is statistically different from 0

We formulate the testable hypothesis: "The average abnormal return is zero".

$$
H_{0}: E\left(R A M_{t}\right)=0
$$

We use Student's t-test to test whether the average abnormal return and the cumulative average abnormal return are statistically different from 0 .

$$
T=\frac{A A R_{t}}{\sigma_{A A R_{t}}} \quad T^{\prime}=\frac{C A A R_{t 1, t 2}}{\sigma_{C A A_{t} R^{\prime}}}
$$

and

where the standard deviation of AAR is determined by Christie (1983) and is given by: 


$$
\sigma_{A A R_{t}}=\frac{1}{\sqrt{N}} \sqrt{\frac{1}{N-1} \sum_{i=1}^{N}\left(A R_{i t}-A A R_{t}\right)^{2}}
$$

Secondly, in order to analyze whether the level of transparency of sovereign wealth funds influence the relation between stock returns and sovereign wealth funds investments, we also use the event study methodology for three groups of samples which depend on the level of transparency. This new approach allows us to analyze clearly the influence of transparency of SWFs on the market reaction to the announcements of SWF investments, which has not been clearly investigated in the previous studies.

\section{Empirical Results}

The table below presents the average abnormal returns for the event window $(-10,10)$.

Table 2. Average abnormal return and the student's t-test

\begin{tabular}{lccc}
\hline Date & AAR $(\%)$ & CAAR $(\%)$ & $t$-test -AAR \\
\hline-10 & -0.29904 & -3.08943 & -0.99 \\
-9 & 0.12027 & -2.96916 & 0.39 \\
-8 & -0.14960 & -3.11876 & -0.52 \\
-7 & 0.71804 & -2.40072 & 1.69 \\
-6 & 0.23587 & -2.16486 & 0.69 \\
-5 & 0.08038 & -2.08448 & 0.25 \\
-4 & 0.16815 & -1.91633 & 0.51 \\
-3 & -0.60728 & -2.52361 & -2.61 \\
-2 & 0.26365 & -2.25996 & 1.26 \\
$\mathbf{- 1}$ & $\mathbf{0 . 6 1 9 5 5}$ & $\mathbf{- 1 . 6 4 0 4 2}$ & $\mathbf{2 . 0 7 * *}$ \\
$\mathbf{0}$ & $\mathbf{0 . 6 7 2 8 7}$ & $\mathbf{- 0 . 9 6 7 5 4}$ & $\mathbf{1 . 7 6 *}$ \\
1 & -0.00952 & -0.97706 & -0.02 \\
2 & 0.16799 & -0.80907 & 0.45 \\
3 & -0.21874 & -1.02781 & -0.62 \\
4 & 0.60669 & -0.42112 & 1.66 \\
5 & 0.49545 & 0.07433 & 1.52 \\
6 & 0.12136 & 0.19568 & 0.47 \\
7 & -0.13936 & 0.05632 & -0.52 \\
8 & -0.06428 & -0.00797 & -0.21 \\
9 & 0.18835 & 0.18039 & 0.65 \\
10 & 0.25160 & 0.43199 & 0.67 \\
\hline
\end{tabular}

${ }^{* *}$ and ${ }^{*}$ represent significance at the $10 \%$ and $5 \%$.

We find that at the particular dates $t=-1$ and $t=0$, the AAR is significantly positive $\left(\mathrm{AAR}_{\mathrm{t}=-1}=0.62 \%\right.$ and $\mathrm{AAR}_{\mathrm{t}=0}=0.67 \%$ ) and the null hypothesis $\mathrm{H}_{0}$ is rejected at $10 \%$ and $5 \%$ level of significance. This means that at the announcement date, the average abnormal return is strongly positive for the firms whose shares are purchased. The results imply that the announcement of SWF share acquisitions coincides with remarkable changes of firm values. The relationship between the stocks return and the sovereign wealth funds acquisitions at the announcement date is also positive and this confirms that the SWF share acquisitions convey positive information to market participants about the firms in which they invest.

Our results are in good agreement with a point of view that SWF investments have positive effects on firm value. These effects originate from the signaling or the ability to impact government actions in ways by which the target firms are supported. Additionally, the firm value shows a favorable respond when SWFs announce investments, which is partially due to the fact that the information generation of stock selection by the funds or SWF investments normally take place in firms facing financial difficulties, especially in the period of financial crisis.

Table 3 reports the cumulative average abnormal returns for different event windows over the period $(t-40, t+$ 20). According to this table, sovereign wealth funds investment generates substantial and positive CAAR during two trading days before and after the announcement of the investment. The average five-day cumulative abnormal returns are 1.71 percent for a $(-2,+2)$ window and 1.28 for a $(-1,+1)$ window. This means around the 
announcement date, the impact of sovereign wealth funds investment on the performance of companies is positive.

Table 3. Cumulative average abnormal return and the student's t-test

\begin{tabular}{lcc}
\hline Event windows & $C A A R(\%)$ & $t$-test $-C A A R$ \\
\hline$(-40,-20)$ & -0.71331 & -0.64 \\
$(-20,-10)$ & -2.42401 & -2.38 \\
$(-10,-5)$ & 0.72561 & 0.92 \\
$(-5,2)$ & 1.33795 & 1.24 \\
$(-3,3)$ & 0.84802 & 0.90 \\
$(-2,2)$ & $\mathbf{1 . 7 1 4 5 4}$ & $\mathbf{2 . 0 5}^{* *}$ \\
$(-\mathbf{1 , 1})$ & $\mathbf{1 . 2 8 2 9 0}$ & $\mathbf{1 . 9 4}^{*}$ \\
$(2,10)$ & 1.45575 & 1.26 \\
$(-20,10)$ & 1.12471 & 0.53 \\
$(10,20)$ & 0.07251 & 0.05 \\
$(-40,20)$ & 0.41185 & 0.13 \\
\hline
\end{tabular}

** and ${ }^{*}$ represent significance at the $10 \%$ and $5 \%$.

It is shown that our results completely support the hypothesis which is proposed above: The market reacts favorably to the announcements of SWF investments. The results are also consistent with the previous studies in which the announcement effect of SWF investment in companies has been determined to be positive. Our estimates of announcement period CAAR for the investment sample are higher than those of Chhaochharia \& Laeven (2008) which is 0.82 percent for a $(-2,+2)$ and Fotak, Bortolotti and Megginson (2008) which is 0.55 percent for a $(-1,+1)$ window. However, our results are lower than those of Kotter and Lel (2008) and Dewenter, Han and Malatesta (2009). Particularly, these authors have measured a CAAR of 2.43 percent for a $(-2,+2)$ and 2.15 percent or 1.7 percent for a $(-1,+1)$ window which are shown in table 4 .

Table 4. Results of the previous studies

\begin{tabular}{lll}
\hline Authors & Event windows & CAAR $(\%)$ \\
\hline Chhaochharia \& Laeven (2008) & $(-2,2)$ & 0.82 \\
Fotak, Bortolotti \& Megginson (2008) & $(-1,1)$ & 0.55 \\
Kotter \& Lel (2008) & $(-2,2)$ & 2.43 \\
& $(-1,1)$ & 2.15 \\
Dewenter, Han \& Malatesta (2009) & $(-1,1)$ & 1.7 \\
\hline
\end{tabular}

The Figures of the AAR and CAAR over the period $(t-40, t+20)$ are shown below.

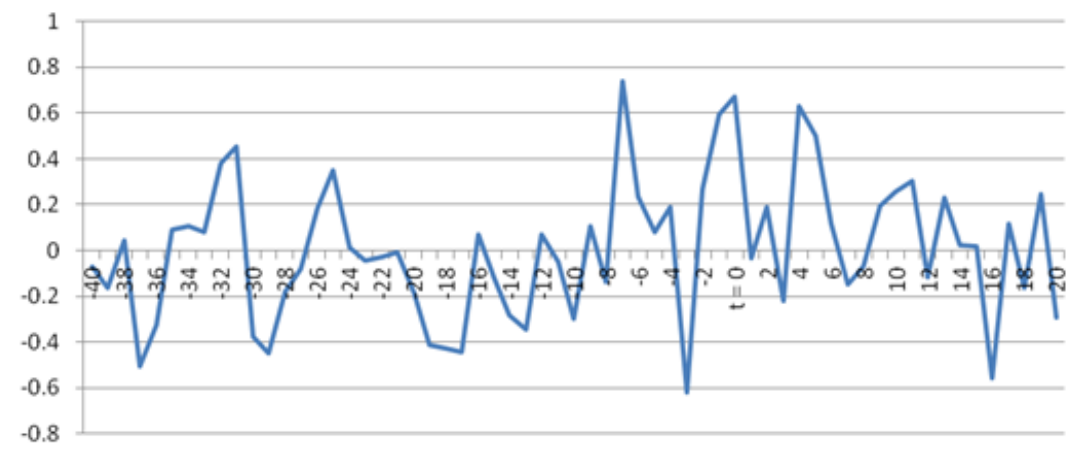

Figure 1. Average abnormal return (\%) 


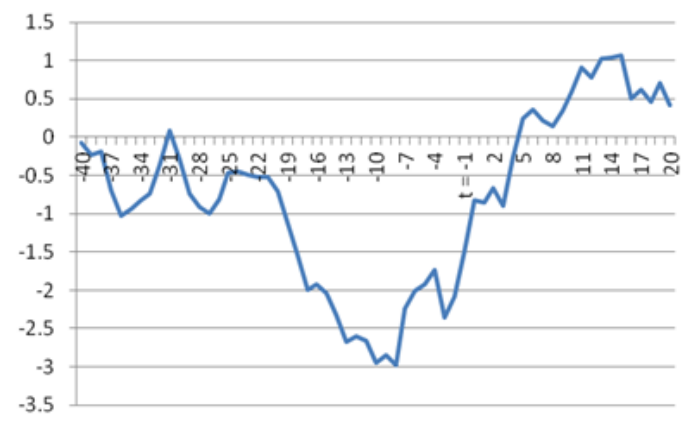

Figure 2. Cumulative average abnormal return (\%)

Next, we verify if the level of transparency of SWFs influences the positive relation between stock returns and sovereign wealth funds acquisitions at the announcement date or not. To achieve this goal, we group and examine the investment of SWFs which have different level of transparency. We use the index Linaburg-Maduell of the Sovereign Wealth fund Institute as a measurement for the transparency of SWFs.

We divide the sample into three groups which depend on the level of transparency:

- Group 1: Investment of sovereign wealth funds having the high transparency (more than 8);

- Group 2: Investment of sovereign wealth funds having the normal transparency (from 6 to 8);

- Group 3: Investment of sovereign wealth funds having the low transparency (less than 6).

Table 5. Transparency of the sovereign wealth funds and the sample

\begin{tabular}{lcc}
\hline Sovereign wealth funds & Linaburg-Maduell (9/2014) & Number of observations \\
\hline Temasek Holdings - Singapore & 10 & 11 \\
Mubadala Development Company - UAE Abu Dhabi & 10 & 1 \\
Group 1 (more than 8) & & $\mathbf{1 2}$ \\
China Investment Corporation (CIC) & 8 & 9 \\
Government of Singapore Investment Corporation & 6 & 14 \\
Kuwait Investment Authority (KIA) & 6 & 3 \\
Group 2 (from 6 to 8) & & $\mathbf{2 6}$ \\
SAFE Investment Company - China & 5 & 4 \\
Qatar Investment Authority (QIA) & 5 & 2 \\
Investment Corporation of Dubai & 5 & 2 \\
Abu Dhabi Investment Authority & 5 & 5 \\
Group 3 (less than 6) & & $\mathbf{1 3}$ \\
Dubai World Holdings Ltd -UAE & N/A & 1 \\
Strategic Investment Fund - France & N/A & 9 \\
Total & & $\mathbf{6 1}$ \\
\hline
\end{tabular}

Source: Sovereign Wealth fund Institute.

We use the event study method and the same steps for the new sample of three groups. The average abnormal return and the cumulative average abnormal return of the three groups are shown in the following tables.

Table 6a. Average abnormal return and the student's t-test: Group 1

\begin{tabular}{lccc}
\hline Date & AAR $(\%)$ & CAAR $(\%)$ & $t$-test-AAR \\
\hline-5 & $-0,52482$ & 0,53740 & -1.10 \\
-4 & 0,64396 & 1,18135 & 1.02 \\
-3 & $-0,18158$ & 0,99977 & -0.57 \\
-2 & 1,13218 & 2,13196 & $\mathbf{2 . 3 0 * *}$ \\
-1 & 0,95798 & 3,08994 & 1.03 \\
$\mathbf{0}$ & $\mathbf{1 , 7 2 7 8 0}$ & $\mathbf{4 , 8 1 7 7 3}$ & $\mathbf{1 . 6 9}$ \\
\hline
\end{tabular}




\begin{tabular}{lccc}
\hline 1 & 2,08645 & 6,90419 & 1.66 \\
2 & $-1,46580$ & 5,43839 & -0.98 \\
3 & 1,43372 & 6,87211 & 1.67 \\
4 & 0,62607 & 7,49818 & 0.62 \\
5 & 0,72134 & 8,21952 & 0.65 \\
\hline
\end{tabular}

** and * represent significance at the $10 \%$ and $5 \%$.

Table 6b. Average abnormal return and the student's t-test: Group 2

\begin{tabular}{lccc}
\hline Date & $A A R(\%)$ & CAAR $(\%)$ & $t$-test - AAR \\
\hline-5 & 0,72559 & $-1,83021$ & 1.15 \\
-4 & 0,37356 & $-1,45665$ & 0.55 \\
-3 & $-0,58865$ & $-2,04530$ & -1.25 \\
-2 & $-0,03440$ & $-2,07969$ & -0.10 \\
-1 & 0,60386 & $-1,47584$ & 1.15 \\
$\mathbf{0}$ & 0,61650 & $-0,85934$ & 1.02 \\
1 & $-0,83092$ & $-1,69026$ & $\mathbf{- 1 . 7 9 *}$ \\
2 & 0,50510 & $-1,18515$ & 0.95 \\
3 & $-0,44149$ & $-1,62664$ & -0.72 \\
4 & 0,65993 & $-0,96671$ & 0.97 \\
5 & 0,41007 & $-0,55664$ & 0.83 \\
\hline
\end{tabular}

* represent significance at the $10 \%$.

Table 6c. Average abnormal return and the student's t-test: Group 3

\begin{tabular}{lccc}
\hline Date & AAR $(\%)$ & CAAR $(\%)$ & $t$-test -AAR \\
\hline-5 & $-1,01164$ & $-5,21472$ & $\mathbf{- 2 . 7 2 * *}$ \\
-4 & $-0,53309$ & $-5,74781$ & -1.32 \\
-3 & $-0,52739$ & $-6,27520$ & -1.76 \\
-2 & $-0,03971$ & $-6,31491$ & -0.11 \\
-1 & 0,47070 & $-5,84421$ & 1.06 \\
$\mathbf{0}$ & 0,75353 & $-5,09068$ & 0.88 \\
1 & $-0,82219$ & $-5,91287$ & -1.24 \\
2 & 0,87692 & $-5,03595$ & $\mathbf{2 . 0 9 *}$ \\
3 & $-0,80160$ & $-5,83755$ & -1.17 \\
4 & 0,83744 & $-5,00011$ & 1.28 \\
5 & 0,31082 & $-4,68929$ & 0.46 \\
\hline
\end{tabular}

** and * represent significance at the $10 \%$ and $5 \%$.

At $\mathrm{t}=0$, the AAR is positive for all three groups. Among them, the ARR and the value of Student's $\mathrm{t}$-test of group 1 is highest $\left(\mathrm{AAR}_{\mathrm{t}=0 \mathrm{G} 1}=1.73 \% ; \mathrm{AAR}_{\mathrm{t}=0 \mathrm{G} 2}=0.62 \%\right)$ and $\left.\mathrm{AAR}_{\mathrm{t}=0 \mathrm{G} 3}=0.75 \%\right) ;\left(\mathrm{T}_{\mathrm{t}=0 \mathrm{G} 1}=1.69 ; \mathrm{T}_{\mathrm{t}=0 \mathrm{G} 2}=\right.$ 1.02 and $\mathrm{T}_{\mathrm{t}}=0 \mathrm{G} 3=0.88$ ). These results indicate that the relationship between the stock returns and SWF acquisitions at the announcement date is positive. In addition, the greater the level of transparency of SWF, the higher the signification of this relation $\left(\operatorname{Pr}>|t|_{t=0 \mathrm{G} 1}=12.14 \%\right.$; $\operatorname{Pr}>|t|_{t=0 \mathrm{G} 2}=31.86 \%$ and $\left.\operatorname{Pr}>|t|_{t=0 \mathrm{G} 3}=39.44 \%\right)$.

The following Figures illustrate the average abnormal return and the cumulative average abnormal return of the three groups.

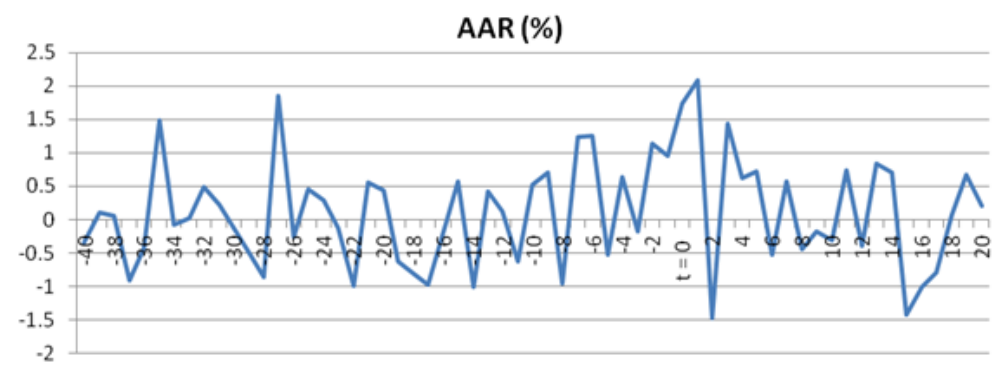

Figure 3a. Average abnormal return: Group 1 (\%) 


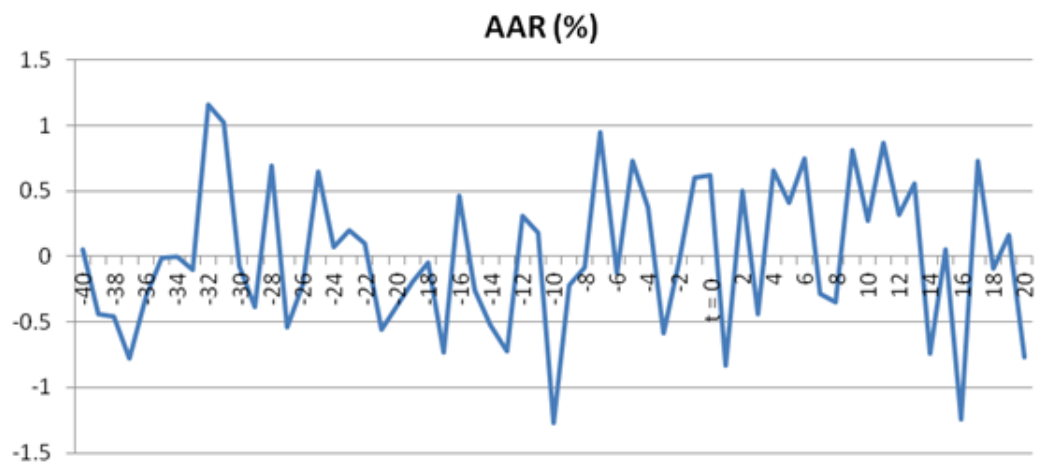

Figure 3b. Average abnormal return: Group $2(\%)$

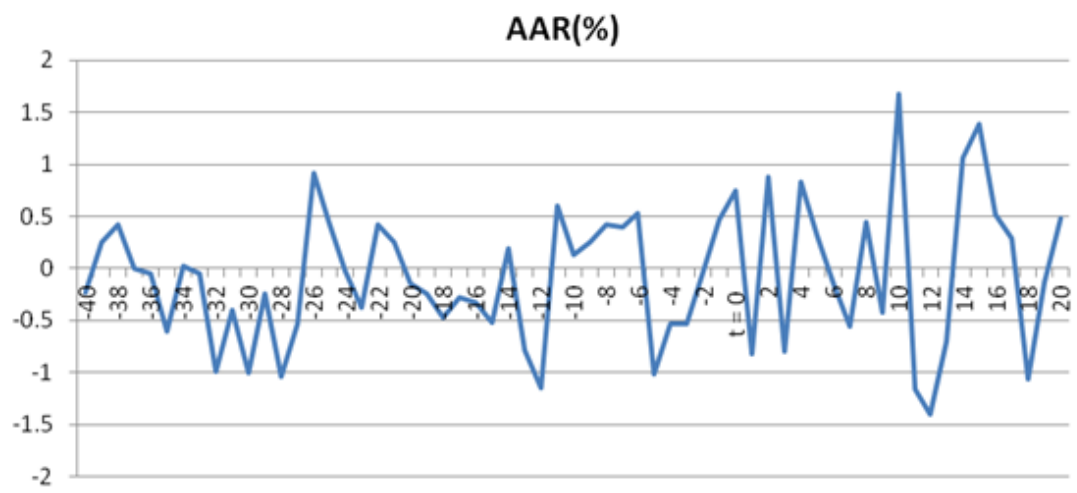

Figure 3c. Average abnormal return: Group $3(\%)$

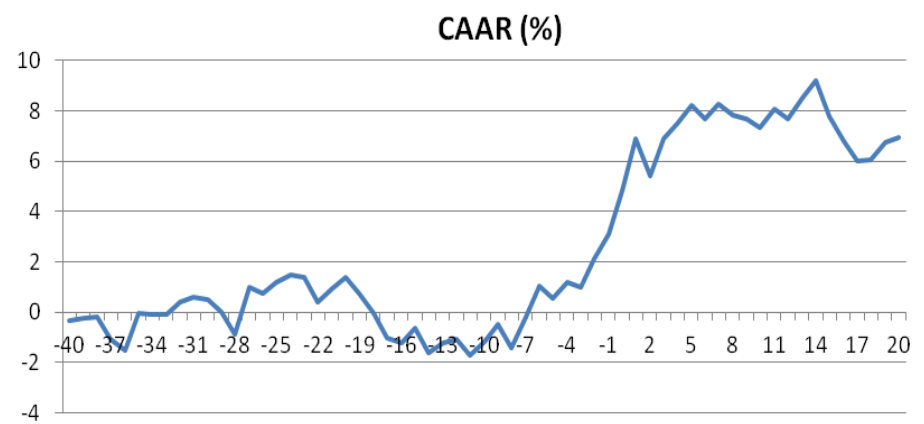

Figure 4a. Cumulative average abnormal return: Group $1(\%)$

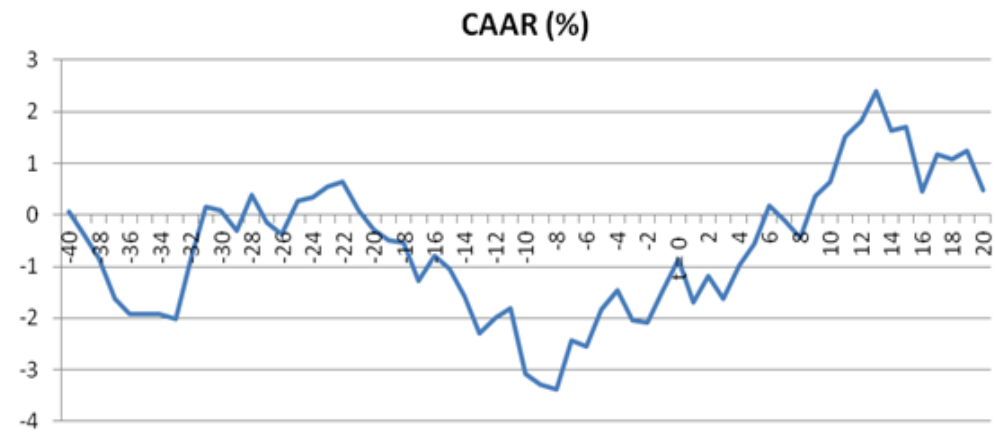

Figure 4b. Cumulative average abnormal return: Group $2(\%)$ 


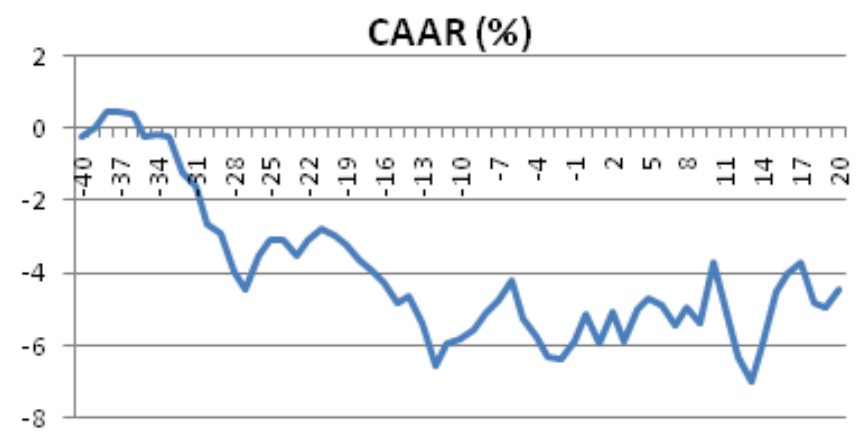

Figure 4c. Cumulative average abnormal return: Group $3(\%)$

The results of the CAAR of three groups are completely different. The tendency of the CAAR of group 1 starts increasing at 6 days before the announcement date. The tendency of the CAAR of group 2 starts increasing at 9 days after the announcement date. On the other hand, the tendency of the CAAR of group 3 keeps decreasing.

We also calculate the CAAR and the Student $t$-test for different event windows over the period $(t-40, t+20)$ and the results are shown below.

Table 7. Cumulative average abnormal return and the student's t-test

\begin{tabular}{lcccccc}
\hline Event windows & \multicolumn{2}{c}{ Group 1 } & \multicolumn{2}{c}{ Group 2 } & \multicolumn{2}{c}{ Group 3 } \\
\cline { 2 - 6 }$(-40,-20)$ & CAAR $(\%)$ & $t$-test & CAAR $(\%)$ & $t$-test & CAAR $(\%)$ & $t$-test \\
$(-20,-10)$ & 1,37289 & 0,58 & $-0,29171$ & $-0,19$ & $-2,93082$ & $-1,82$ \\
$(-10,-5)$ & $-2,12540$ & $-0,82$ & $-3,15850$ & $-2,10$ & $-3,01036$ & $-1,86$ \\
$(-5,2)$ & 2,24332 & 1,91 & $-0,02803$ & $-0,02$ & 0,71382 & 0,78 \\
$(-\mathbf{3 , 3})$ & 4,37617 & 1,04 & 1,37064 & 0,91 & $-0,83287$ & $-0,70$ \\
$(-2,2)$ & $\mathbf{5 , 6 9 0 7 6}$ & $\mathbf{2 , 5 0 * *}$ & $-0,16999$ & $-0,11$ & $-0,08974$ & $-0,05$ \\
$(-\mathbf{1 , 1})$ & 4,43861 & 1,33 & 0,86014 & 0,72 & 1,23925 & 1,32 \\
$(2,10)$ & $\mathbf{4 , 7 7 2 2 3}$ & $\mathbf{2 , 1 9 *}$ & 0,38944 & 0,48 & 0,40204 & 0,35 \\
$(-20,10)$ & 0,44310 & 0,12 & 2,33132 & 1,55 & 2,22700 & 0,83 \\
$(10,20)$ & 6,41150 & 0,93 & 0,55492 & 0,20 & $-0,89513$ & $-0,18$ \\
$(-40,20)$ & $-0,71430$ & $-0,27$ & 0,10799 & 0,05 & 0,93126 & 0,28 \\
\hline & 6,94201 & 1,10 & 0,47562 & 0,08 & $-4,43285$ & $-0,57$ \\
\hline
\end{tabular}

For group 1 , the CAAR and Student t-test show that the CAAR for 7 days $(-3,+3)$ and 3 days $(-1,+1)$ are strongly positive (especially at the 5\% and 10\%). For group 2 and group 3, around the announcement date, the CAAR for the 5 days $(-2,+2)$ and 3 days $(-1,+1)$ are positive. However, these values are low and the Student t-test does not show that the CAAR for these event windows are significantly different to 0 .

Comparing the results of the sovereign wealth funds having the high transparency (group 1) with those having the normal and low transparency (group 2 and group 3, respectively), we find that for the announcement date, the AAR of group 1 is highest and this value decreases with respect to the level of transparency of sovereign wealth funds. Around the announcement date, the CAAR of group 1 is higher than that obtained in the case of group 2 and group 3.

Our findings show that the level of transparency of SWF influences the positive reaction of the announcement of SWF acquisition on the share prices of the companies.

\section{Conclusion}

Recently, Sovereign Wealth Funds have attracted a lot of considerable attention of economists; however, very little academic research has been carried out in this subject. We have verified whether the effect of SWF investments in companies on balance creates or reduces value by examining the returns to target firm shareholders subsequent to these investments. By dividing the sample into different groups depending on the level of transparency, we have analyzed clearly the influence of transparency of SWFs on the market reaction to 
the SWF investments, which has not presented in the previous studies. We have also found that the short-term impact of SWF investments on the performance of the companies in which they invest is positive. The level of transparency of SWFs influences the positive impact on the performance of those companies and the greater the level of transparency of SWF, the stronger the positive reaction. Our findings would enhance current understandings of SWF impact on the subsequent performance of the listed companies in which they invest and improve the performance of SWFs and of the firms that attract SWF investments.

\section{References}

Chhaochharia, V., \& Laeven, L. (2008). Sovereign Wealth Funds: Their Investment Strategies and Performance. Working paper, International Monetary Fund, p. 48. Retrieved from http://www.cepr.org/active/publications/discussion_papers/dp.php?dpno=6959

Christie, A. (1983). On Information Arrival and Hypothesis Testing in Event Studies. Working paper, University of Rochester, Rochester, NY, p. 78. http://hdl.handle.net/1802/4856

Deventer, K. L., Han, X., \& Malesta, P. H. (2009). Firm Value and Sovereign Wealth Fund Investments. Working Paper, University of Washington, p. 59.

Fotak, V., Bortolotti, B., \& Megginson, W. (2008). The Financial Impact of Sovereign Wealth Funds Investments in Listed Companies. Working Paper, University of Oklahoma, p. 47. Retrieved from http://www.privatizationbarometer.it/rullo/SWF.pdf

In, F., Park, R., \& Lee, B. (2013). Do Sovereign Wealth Funds Stabilize Stock Markets? Working Paper, Monash University, p. 47. http://dx.doi.org/10.2139/ssrn.2276625

International Monetary Fund. (2011). Global Financial Stability Report, Chapter 2 "Long-term Investors and Their Asset Allocation: Where Are They Now? (Washington: International Monetary Fund, September).

Knill, A., Lee, B., \& Mauck, N. (2012). Sovereign wealth fund investment and the return-to-risk performance of target firms. Journal of Financial Intermediation, 21, 315. http://dx.doi.org/10.1016/j.jfi.2011.10.001

Kotter, J., \& Lel, U. (2008). Friends or foes? The stock price impact of Sovereign Wealth Fund investments and the price of keeping secrets. International Finance Discussion Papers, $\mathrm{n}^{\circ}$ 940, Washington: Board of Governors of the Federal Reserve System. Retrieved from http://www.federalreserve.gov/Pubs/ifdp/2008/940/ifdp940.htm

Nuno, F. (2009). Sovereign Wealth Funds: Investment choices and implications around the world. Working paper, European Corporate Governance Institute. Retrieved from http://www.imd.org/research/publications/upload/wp_2009_01_fernandes_level_1.pdf

Papaioannou, M., Joonkyu, P., Jukka, P., \& Han, V. D. H. (2013). Procyclical Behavior of Institutional Investors During the Recent Financial Crisis: Causes, Impacts, and Challenges. IMF Working Paper 13/193 (Washington: International Monetary Fund). http://dx.doi.org/10.5089/9781484336083.001

Sojli, E., \& Tham, W. W. (2010). The Impact of Foreign Government Investments on Corporate Performance: Evidence from the U.S. Finance Meeting EUROFIDAI-AFFI, Paris. http://dx.doi.org/10.2139/ssrn.1540555

\section{Appendix}

The list of the companies which are used for the sample

\begin{tabular}{lll}
\hline SWF & Company & Country \\
\hline Government of Singapore Investment Corporation (GIC) & Beijing Capital Land Ltd & China \\
& Thakral Holdings Group & Australia \\
& AEI & Singapore \\
& UBS & Switzerland \\
& GPT Group Ltd & Australie \\
& British Land Co Plc & UK \\
& Anant Raj Industries Ltd & India \\
& Liberty International Plc & UK \\
& Citigroup & US \\
& China Vanke & China \\
\hline
\end{tabular}




\begin{tabular}{|c|c|c|}
\hline & ICICI Bank & India \\
\hline & Bangkok Bank & Thailand \\
\hline \multirow[t]{11}{*}{ Temasek Holdings - Singapore } & Global Crossing Ltd & US \\
\hline & Standard Chartered Plc & UK \\
\hline & Olam International Limited & Singapore \\
\hline & Vical Inc & US \\
\hline & Equinix Inc & US \\
\hline & Citic Resources Holdings Limited & Hong Kong \\
\hline & ICICI Bank Ltd & India \\
\hline & Merrill Lynch & US \\
\hline & China Eastern Air & China \\
\hline & Barclays Bank & UK \\
\hline & Vinamilk & Vietnam \\
\hline \multirow[t]{9}{*}{ China Investment Corporation (CIC) } & Teck Resources Limited & Canada \\
\hline & Morgan Stanley & US \\
\hline & Veolia & France \\
\hline & GCL-Poly Energy Holdings Ltd & China \\
\hline & AES Corporation & US \\
\hline & Total & France \\
\hline & Diageo plc & UK \\
\hline & Noble G roup & Hong Kong \\
\hline & BG Group & UK \\
\hline \multirow[t]{9}{*}{ Strategic Investment Fund - France } & Technip & France \\
\hline & Nexans & France \\
\hline & Gemalto & Netherlands \\
\hline & France Telecom & France \\
\hline & $\mathrm{ADP}$ & France \\
\hline & Séché Environnement & France \\
\hline & Effiage & France \\
\hline & Eutelsat communications & France \\
\hline & Danone & France \\
\hline \multirow[t]{5}{*}{ Abu Dhabi Investment Authority (ADIA) } & Suez Cement Company & Egypt \\
\hline & Citigroup & US \\
\hline & Toll Brothers & US \\
\hline & Mediaset SPA & Italia \\
\hline & AMP NZ Office Trust & New Zealand \\
\hline \multirow[t]{4}{*}{ SAFE Investment Company - China } & Total & France \\
\hline & $\mathrm{BP}$ & UK \\
\hline & Commonwealth Bank of Australia & Australia \\
\hline & Australia and New Zealand Banking Group & Australia \\
\hline \multirow[t]{3}{*}{ Kuwait Investment Authority (KIA) } & Citigroup & US \\
\hline & Merrill Lynch & US \\
\hline & Mahindra \& Mahindra Limited & India \\
\hline \multirow[t]{2}{*}{ Qatar Investment Authority (QIA) } & Credit Suisse & Switzerland \\
\hline & Barclays Bank & UK \\
\hline \multirow[t]{2}{*}{ Investment Corporation of Dubai (ICD) } & EADS N.V. & Netherlands \\
\hline & Sony & Japan \\
\hline Dubai World Holdings Ltd -UAE & MGM Mirage & US \\
\hline Mubadala Development Company - UAE Abu Dhabi & Advanced Micro Devices Inc-AMD & US \\
\hline
\end{tabular}

\section{Copyrights}

Copyright for this article is retained by the author(s), with first publication rights granted to the journal.

This is an open-access article distributed under the terms and conditions of the Creative Commons Attribution license (http://creativecommons.org/licenses/by/3.0/). 